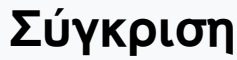

Tó 17 (2006)

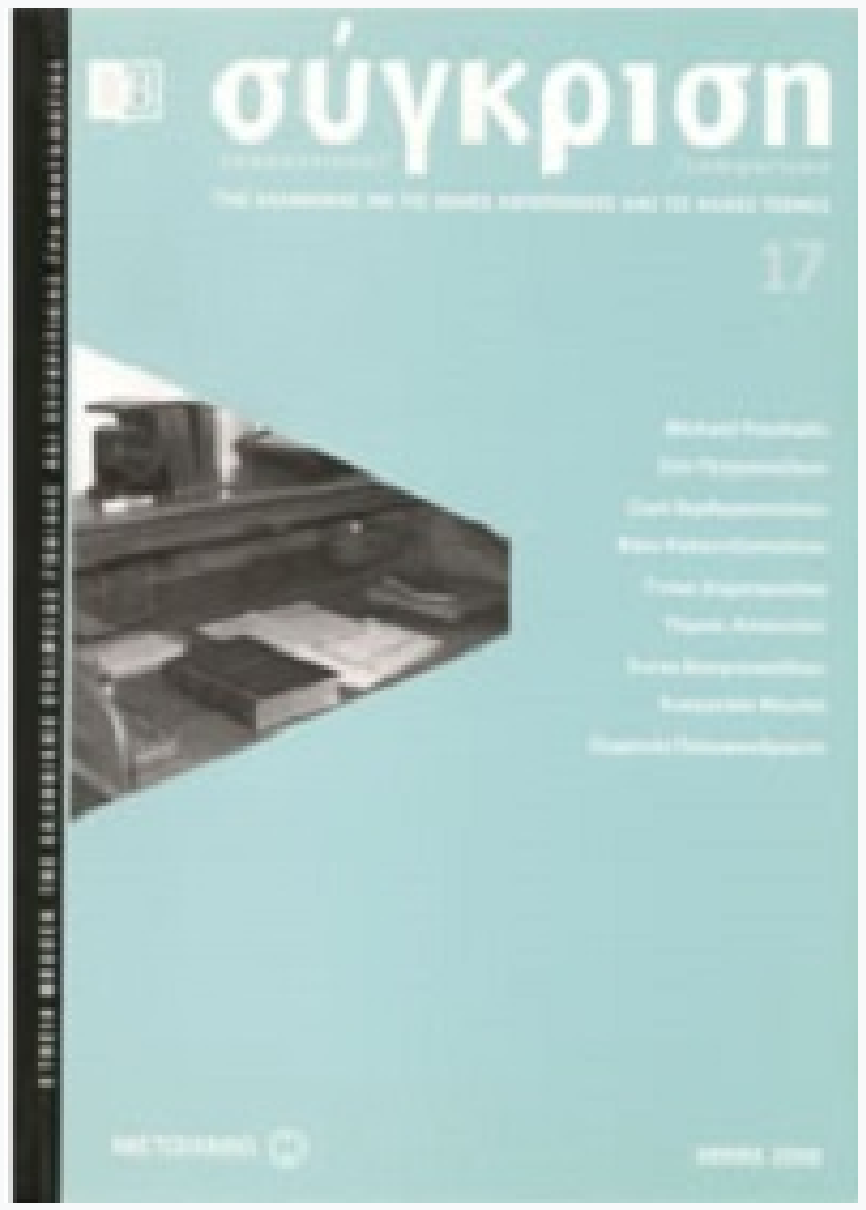

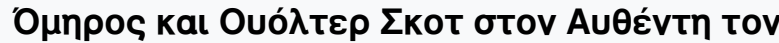

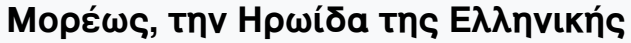

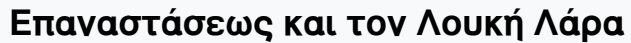

\section{Michael Paschalis}

doi: $\underline{10.12681 / \text { comparison.10150 }}$

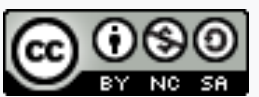

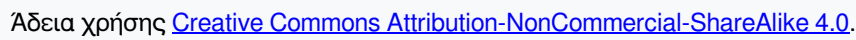

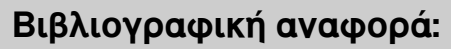

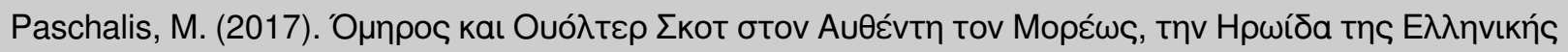

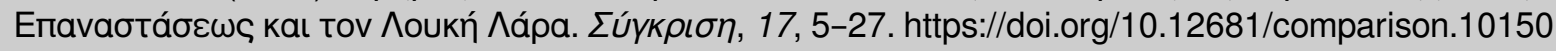




\title{
MICHAELPASCHALIS
}

\author{
Homer and Walter Scott \\ in The Lord of Morea, \\ The Heroine of the Greek Revolution, \\ and Loukis Laras
}

1 odern Greek identity during the period of the Greek Enlightenment and constructed with reference to ancient Hellenism. Interest in classical antiquity continues after Greece won its independence from Ottoman rule. From the early 1850 s, the world of Byzantine Hellenism gradually comes to the fore in the field of historical research and writing: the pattern of historical continuity introduced by Konstantinos Paparrigopoulos (in the History of the Greek Nation, 1860-1874) now embraces Christian and Medieval Hellenism and defines Greek identity as a unified entity of 3000 years. However, Greek novels published until $1884^{1}$ continue to engage in dialogue primarily with classical antiquity, regardless of the period in which the action is set, ${ }^{2}$ and only exceptionally with the world of Byzantium. In these novels the reception of Greek and/or Roman antiquity is most commonly unmediated, from ancient to modern times (or the dramatic time of the story), from ancient to modern Hellenism. In cases where Byzantium makes a timid appearance, the novelists' attitude tends to be hostile or derisive, ${ }^{3}$ but we may also catch a glimpse of the "Great Idea". This is a project first formulated vaguely in 1843-1844 that went through various phases and covered a wide range of aspirations, from reclaiming the Byzantine cultural inheritance and promoting the continuity of Hellenism to the re-conquest of Constantinople and the resurrection of the Byzantine Empire.

The year 1850 marks the publication by Alexandros Rangavis of The Lord of Morea, commonly considered the first Greek historical novel. Its action is set in the period of Frankish domination of the Peloponnese and its plot is derived partly from the medieval Chronicle of Morea-versions of which were published by Buchon in 1825, 1840 and $1845^{4}$ - and partly from Walter Scott's Ivanhoe. Scott's novel also constitutes the major literary influence on The Lord of Morea. Direct references to classical antiquity are few, but ancient Hellenism plays 
nonetheless an important role from an ideological and literary aspect. The present study deals especially with the construction of the novel's plot and characters, examining the fusion of Scott's Ivanhoe with The Chronicle of Morea and the interaction with Homer's epics. Scott's historical novel already declares its debt to Homer's Odyssey in the epigraph for chapter 1; this study explores the complex relationship of The Lord of Morea to both texts, as well as to Homer's Iliad, to which Ivanhoe is also, though much less, indebted..$^{\mathbf{5}}$ It will turn out that the re-examination of literary issues entails the re-evaluation of ideological ones.

Discussing the construction of the plot of a historical novel modeled after Scott -the writer credited with the foundation of this novelistic subgenreinevitably touches upon a controversial question: the extent and nature of Walter Scott's influence on the Greek historical novels of the $19^{\text {th }}$ century. ${ }^{6}$ The view adopted here is that The Lord of Morea is the first and only historical novel in Scott's terms. It displays in its own way what is perhaps the cardinal plot shape of Scott's novels: a crisis in historical life with clashing political forces and a hero whose function is to bring the extremes into contact with each other. ${ }^{7}$ The claim to the Lordship of Morea that provokes the crisis is a story drawn from The Chronicle of Morea, but Rangavis, through a dramatic compression of events, weaves in a clash between the Franks and the conquered Greeks inspired by Ivanhoe and makes of both a single "action" (as Aristotle would have said) rounded off with the original idea of a "Great Hunt". As will be seen below, the true protagonist is Geoffrey de Villehardouin who in the end becomes Lord of Morea and achieves the reconciliation between the Franks and the Greeks; Leon Chamaretos, the hero on the Greek side, has views that are too strong (much stronger than Cedric's in Ivanhoe) to survive the reconciliation and so he kills himself. In a sense the tight plot of Rangavis' novel as manifested in the organization of action around Geoffrey de Villehardouin improves on the weaknesses of Ivanhoe's plot, which have been pointed out more than once. ${ }^{\mathbf{8}}$

The present study examines in brief two more historical novels: The Heroine of the Greek Revolution by Stephanos Xenos (1861) and Loukis Laras by Dimitrios Vikelas (1879). Both novels satisfy the requirement of prescribed time distance from the writer's present ${ }^{9}$ and have fictional or fictionalized characters moving against a historical background, but they cannot be termed "historical" in the terms of Walter Scott's novels, though both have been believed to reflect Walter Scott's method of composition. They will serve as examples for showing differences in plot and character from The Lord of Morea as well as differences in handling the same material from classical antiquity, Homer's epics. In the first of 
these novels classical material is overwhelming and the copious similes, metaphors and footnotes through which it is introduced ${ }^{\mathbf{1 0}}$ function independently without creating literary depth. By contrast The Lord of Morea uses few references that work at an intertextual level and create a second level of reading.

I chose ancient epic to represent classical material for a variety of reasons. Epic is the founding Western narrative genre and the chief narrative genre of antiquity; the novel is the chief narrative genre of modern times; ancient and modern novelists have frequently felt the need to enter into dialogue with epic and its descendants (like the Renaissance romanzo); and theorists, especially Georg Lukács and Mikhail Bakhtin, have been eager to distinguish the modern novel from epic, thus indirectly recognizing existing affinities between the two genres. It is noteworthy that Boccaccio's Filocolo, considered by some to be the first modern novel, relates programmatically to Virgil's Aeneid ${ }^{\mathbf{1 1}}$ and that in the influential Lettre-traité de l'origine des romans, written in 1670 and considered the first systematic study of the novel, Pierre Daniel Huet praised the ancient Greeks for giving the novel its perfect form "by placing it under the rules of Epic" ("en le resserrant sous les règles de l'épopée”), by which he meant Homeric epic.

\section{The Lord of Morea}

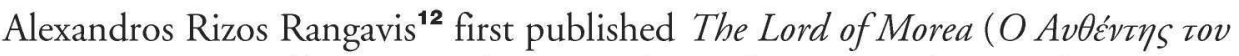

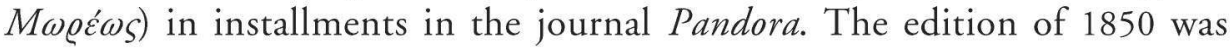
reprinted with revisions first in 1857 and then in 1876, in the eighth volume of the author's Collected Literary Works. ${ }^{13}$ Rangavis used his vast knowledge of antiquity very sparingly in The Lord of Morea in comparison with the copious material found in Stephanos Xenos' The Heroine of the Greek Revolution or Emmanuel Roidis' Pope Joan. ${ }^{14}$ Chapters 17-18 of the Lord of Morea, where the narrator takes advantage of Robert's unintentional wandering in order to provide archaeological and historical material for certain sites of the Peloponnese, is the closest parallel in Rangavis - but considerably less detailed and extensive. In these chapters and elsewhere Rangavis points to vestiges of ancient Greece and the heritage of ancient Hellenism at the time of the occupation of Byzantine Peloponnese by the Franks. In an authorial intervention that adapts Scott's words in Ivanhoe, ${ }^{15}$ Rangavis talks about the Franks that came and left without leaving traces of their presence, names and memory except for castle ruins and escutcheons; and, expanding Scott's comment, he adds that even these remnants will not attract the interest of travelers, who will instead "hasten towards the 
Cyclopean walls of the glorious age [ancient Greece] and towards the inimitable creations of ancient chisels". ${ }^{16}$ Though this is a romantic era, Rangavis is adopting a neoclassical discourse ${ }^{\mathbf{1 7}}$ and, as it will be seen below, the ideological precedence of ancient Hellenism is a pervading feature in the novel. On the other hand, Leon Chamaretos aspires to restore the "holy throne of the emperors", ${ }^{18}$ and this has led Mario Vitti to describe The Lord of Morea as the "literary equivalent of the Great Idea". ${ }^{19}$ At this early stage, however, Byzantium has not yet become "an integral component of Greek identity" 20 and hence in Rangavis' novel it has "no substance": it is a mere shell that houses ancient Hellenism and Leon's "Lacedaemonian" ideology, which I will discuss below.

\section{The Chronicle of Morea, The Lord of Morea, and Walter Scott's Ivanhoe}

The plot of The Lord of Morea is based partly on a story found in The Chronicle of Morea, a medieval text dating to about 1300 A.D. It narrated in verse the conquest of Morea (i.e. the Peloponnese) by the Franks following the Fourth Crusade (11981205) and the capture of Constantinople. The story taken from The Chronicle concerns an agreement made between William de Champlitte, the departing Lord of Morea, and Geoffrey de Villehardouin. ${ }^{21}$ The pact ran as follows: should William fail to return or send a successor within a year and one day from the date of his departure, his rights to the Lordship of Morea would be transferred to Geoffrey. During his absence Geoffrey completed the occupation of the Peloponnese and won the love of Franks and Greeks alike, who persuaded him to use all possible means to retain power. When William named his young nephew Robert de Champlitte as his successor, Geoffrey tried everything to avert or delay his coming from France to the Peloponnese; it was a long journey that involved the crossing of the Alps and the passage to Venice, sailing to Corfu and from there to the western Peloponnese. New delays followed in the Peloponnese, when Robert vainly chased Geoffrey around in an effort to meet him and achieve a formal transfer of office. Eventually, however, the deadline in the agreement expired, Geoffrey was proclaimed the rightful Lord of Morea and Robert departed for France. ${ }^{22}$

A major literary influence on The Lord of Morea is Sir Walter Scott's Ivanhoe. Rangavis was married to Caroline Skene, daughter of James Skene who was a close friend of Walter Scott. ${ }^{23}$ In an authorial intervention that appeared for the first time in the $3^{\text {rd }}$ edition of Ivanhoe, ${ }^{\mathbf{2 4}}$ Rangavis openly declares his debt to Walter Scott: 


\begin{abstract}
"Shade of the greatest of contemporary novelists, will you rise up against my Black Knight and challenge it for being a loan from the inexhaustible treasure of your brilliant imagination? And must I suppress one of the foremost events of this memorable athletic contest only in order to avoid crossing your path? No, I must not! Forced as I am to follow your tracks, what better choice do I have but to express myself as you did? The fear that I may be criticized for imitating you is not going to stop me; on the contrary, I will take pride in attaching myself to the vehicle of your genius and will not abandon my Black Knight because he recalls one of the most beautiful creatures of your imagination".
\end{abstract}

(The Lord of Morea, pp. 60-61)

The action of Ivanhoe takes place in 1193-4, some fifteen years earlier than the action of The Lord of Morea. It has been suggested that The Lord of Morea is a hybrid creation where two themes are clumsily brought together: the surface theme of the "pact" between William and Geoffrey deriving from The Chronicle, and a deeper theme, the struggle between Greeks and Franks based on the struggle between Saxons and Normans in Scott's Ivanhoe, with Leon Chamaretos playing the part of Cedric the Saxon. This approach identifies also a further, third, theme consisting in "two love stories". ${ }^{25}$

The truth of the matter is that Rangavis created a tight and unified plot out of The Chronicle, Scott's Ivanhoe, and invented material by organizing the course of events around Geoffrey. From early in the novel to its very end Geoffrey de Villehardouin strives to win the Lordship of Morea, to consolidate his power, and, by means of the marriage of his son Geoffrey II -planned secretly with the aid of Venedictos, the Latin Bishop of Olena- to serve his ulterior ambitions for the throne of Constantinople. ${ }^{\mathbf{2 6}}$ Through his intrigues, his scheming agents and his virtuoso moves Geoffrey masterminds three enterprises: first, the deception of Robert and the accession to the Lordship of Morea, the story adapted from The Chronicle, next, the marriage of his son Geoffrey II with Agnes, niece of the Latin Emperor of Constantinople, an event which in The Chronicle occurs after the death of Geoffrey I and in which it is Geoffrey II that makes all the moves; ${ }^{\mathbf{2 7}}$ and, finally, tracking down the Greek insurgents headed by Leon Chamaretos and achieving their surrender and his recognition by them as Lord of Morea. Thus, relying on the construction of the plot alone, we can see that the ideological model -if the novel is indeed "proposing” one- for the Greeks of Rangavis' times who nurtured hopes for a brighter future would turn out to be not the romantic, patriotic but naïve Leon, but Geoffrey, the shrewd diplomat and efficient politician. $^{\mathbf{2 8}}$

Rangavis found in Scott's Ivanhoe not just a narrative precedent for the 
struggle between the Greeks and the Franks but also a remarkable parallel to the plot drawn from The Chronicle. In Ivanhoe the country is ruled by the wicked and ambitious Prince John, while Richard, the rightful king, is held prisoner in Austria. Prince John uses every means possible to prevent his return to the country and to power, and to reinforce his position against the legitimate successor in case Richard dies abroad. Cedric the Saxon desires to restore things as they were before the Norman conquest and for this purpose counts on the marriage of his ward Lady Rowena with Athelstane, the last descendant of the Saxon kings; Lady Rowena eventually marries Ivanhoe, Cedric's son, who has, however, adopted the ways of the Normans. The marriage is emblematic of the reconciliation between Normans and Saxons.

The exercise of power in the absence of the rightful ruler $^{29}$ and systematic attempts to prevent his return are major points of contact between The Chronicle, The Lord of Morea, and Ivanhoe - the only difference being that in The Chronicle and The Lord of Morea it is not the Lord (King) himself that returns but his successor. Under the influence of Scott, Rangavis also gives space to love: the love of Anna, daughter of the Greek Despot of Epirus, for Guy de la Roche, nephew of the Duke of Athens, who is in the Peloponnese disguised as a knight by the name Gautier (cf. Scott's Ivanhoe); and the unreciprocated love of Leon Chamaretos for her too. But these are not mere "romantic loves", as has been suggested. Rangavis manipulates them in the context of dynastic plans in a distinctly subtler way than Walter Scott. The scheming Petraleifas, father-in-law of the Despot of Epirus and Geoffrey's only worthy opponent, is putting pressure on the Despot's unwilling daughter Anna to marry the successor to the Lordship of Morea, whoever he may be - initially he promotes Robert's arrival in the Peloponnese through his agent Nonnos. At the same time Petraleifas is using Anna as a lure to exercise control over Leon Chamaretos, who is in love with her and also aspires to restore past Greek glory: he persuades Leon to rise against the Franks, siding with Robert against Geoffrey. ${ }^{30}$ For his part Geoffrey has other plans for the marriage of his son, is keeping an eye on the moves of Petraleifas through his agents, manages to mislead him through clever manoeuvers, and forces him, with concealed threats and vague promises, to deliver the list of the insurgents and their secret signals. ${ }^{31}$ Petraleifas' main intrigue fails: love triumphs in the case of Anna and Guy (Gautier), a marriage which is irrelevant to the succession in the Lordship of Morea and which occurs much later in The Chronicle; $;^{\mathbf{3 2}}$ and Geoffrey's secret plan carries the day: his son and rightful successor marries the niece of the Latin emperor of Constantinople. 


\section{The six Odysseys}

Critics rarely, if ever, note that Scott's Ivanhoe, the most popular of his novels, begins with a conscious allusion to the Odyssey. I quote (with minor additions) the following short summary of similarities to Homer's epic given by John Henry Raleigh, the only piece of secondary literature available:

“The epigraph ... for Chapter One is a quote from Pope's translation of the Odyssey... The quotation is about the swine being driven home at evening; so we know that we are with [the swineherd] Eumaeus and that the disguised Odysseus is about to appear. Gurth, the slave of the Saxon Cedric driving home the swine helped by his dog, plays Eumaeus, and is twice so-called by Scott ["This second Eumaeus"]. Ivanhoe, returning home from the $3^{\text {rd }}$ Crusade in the Holy Land [and disguised as a palmer] is Odysseus. Rotherwood, the ancestral home of Cedric the Saxon, is Ithaca, and Rowena, ever faithful to Ivanhoe as she awaits his return, is its Penelope. Antinous is played by the villain of Ivanhoe, the Norman Knight, Sir Brian de Bois-Guilbert. Thus at a sumptuous feast at Rotherwood, introduced by another appropriate quote from Pope's Homer, the disguised Ivanhoe has to endure seeing the lustful Sir Brian casting his lascivious glances at the fair and chaste Rowena. That evening, the still disguised Ivanhoe has an interview with Rowena who, like Penelope in Book XIX of the Odyssey, is for the occasion seated on a very elegant chair and has a bevy of handmaids at her service. Finally, on a different time-scale from the Odyssey, Ivanhoe reveals his true identity to Gurth. In a larger sense the Normans play the role of the suitors in the Odyssey, living off the best of the substance of the subjugated Saxons. Says Gurth: 'The finest and fattest is for their board; the loveliest is for their couch". ${ }^{33}$

I will argue below that the Odyssey also functions as a subtext for The Lord of Morea and for the narrative of Rangavis' coming to Greece in 1829 as given in his Memoirs. Inspiration probably came from different sources: (a) Scott's use of the Odyssey; (b) Rangavis' own reading and translation of the Odyssey: in 1840 Rangavis translated book 1 of the Odyssey into modern Greek hexameters but later gave up the plan to translate the rest of Homer's epic; ${ }^{34}$ and (c) a Greek translation of Ivanhoe: in 1847, three years before the publication of The Lord of Morea, Gheorghios Lampissis translated Ivanhoe into Greek, ${ }^{35}$ restoring the original Homeric text in the epigraphs for chapters 1, 4 and 13. Thus we end up with six Odysseys: the Greek original, Rangavis' translation (accomplished and originally projected), and four subtexts (in Ivanhoe, The Lord of Morea, the translation of Ivanhoe, and the Memoirs).

In The Lord of Morea direct allusions to Homer's Odyssey occur where most expected: in the section that treats Robert's journey deliberate delays engineered by Geoffrey's agent are compared to Penelope's weaving scheme and to the distracting "pleasures of Circe". ${ }^{36}$ But more important is the less obvious 
intertextual relationship. The absence of the rightful ruler, the claim to his power, and the obstacles that delay the return of the ruler are central themes of Homer's Odyssey found both in Ivanhoe and in The Lord of Morea. In the Odyssey and in The Lord of Morea the journey of return is given great emphasis, whereas in Ivanhoe the plot requires that we only hear of the obstacles encountered. In the Odyssey and in The Lord of Morea the conflict of power involves respectively father and son (Odysseus and Telemachus, rightful successor) and uncle and nephew (William and Robert, rightful successor). The attempts to avert the return of Telemachus from Sparta by killing him are picked up by the attempts to avert or delay Robert's coming to the Peloponnese. In The Lord of Morea, however, it is Geoffrey that eventually succeeds William and not Robert, who is the legitimate successor. But there is a significant difference: in terms of his military exploits and the treatment of his subjects Geoffrey does not resemble Prince John and the Norman knights, or the suitors of Homer's Odyssey. Rangavis developed and enriched an image of Geoffrey he found in The Chronicle. ${ }^{37}$ In this narrative Geoffrey appears worthy of the Lordship of Morea for being the real conqueror of the Peloponnese, for enjoying the love of most Greeks $^{\mathbf{3 8}}$ and for being far superior to the two other claimants: the brave and noble but naïve and unsuspecting Chamaretos, and the weak-willed, foolishly ambitious and gullible Robert who had never fought a battle in his life.

Similarities of The Lord of Morea with the Odyssey and Ivanhoe surface also in other areas. "Disguise" plays an essential part in all three texts: Odysseus, Richard, and Ivanhoe coming home in disguise have their counterpart especially in Raimondos, Geoffrey's trusted agent, who returns to the Peloponnese disguised as a monk. ${ }^{39}$ Also, the character of Geoffrey may have absorbed features of Odysseus. His cunning and shrewd moves, which enable him to win the succession at the expense of Robert, are viewed positively; these qualities could be construed as the counterpart of Homeric metis ${ }^{\mathbf{4 0}}$ and the equivalent of efficient diplomacy in Rangavis' days.

After the long delay in Venice eventually Robert sets sail aboard a ship given to him by the Doge; but when they make a stop at Corfu for repairs, the captain sails away secretly during the night abandoning Robert. ${ }^{41}$ With great efforts Robert manages to find a boat to the Peloponnese, having been forced to abandon his escort on the island. ${ }^{42}$ Already in antiquity Corfu became identified with Scheria, the island of the Phaeacians; it was Odysseus' last stop before his return to Ithaca, where he arrived aboard a ship of the Phaeacians and without his companions. 
In his Memoirs Rangavis describes his first arrival in Greece from Munich in 1829. ${ }^{43}$ The route of the journey (crossing of the Alps to Trieste and from there to Venice, crossing of the Adriatic, arrival at the Ionian islands), the time of the year (late fall and winter) and especially the difficulties encountered (snowcovered Alps, delay in Venice and difficulties in finding a ship, and the long and adventurous voyage across the stormy Adriatic) remind the reader of Robert's journey in The Chronicle and The Lord of Morea. For Robert as designated successor to the Lordship of Morea and for the Phanariot Rangavis this is a kind of homecoming (nostos); and Rangavis exploits the nostos theme by providing an Odyssean intertext for his first sight of the Ionian islands, his failure to recognize the fatherland, and other features. The Odyssean fiction of Rangavis' Adriatic crossing found in the Memoirs replaces an earlier Argonautic one found in two short stories that describe the same voyage. ${ }^{44}$

This Odyssean intertext surfaces first when the passengers of the storm-tossed ship sailing across the Adriatic sight from a distance "the islands of the Phaeacians and of Odysseus", just as Odysseus in Odyssey 5 after a voyage of eighteen days from the island of Calypso sights the island of the Phaeacians. ${ }^{45}$ But the storm Poseidon raises causes Odysseus' raft to fall apart and it is only with divine help that the hero swims to Scheria. In the Memoirs Rangavis and his fellowpassengers enter with difficulty, due to the stormy seas, and just before midnight an island harbor, believing to have reached the city of Zakynthos. They experience literary dreams that echo Odyssey 19 and anticipate the frustration to follow. ${ }^{46}$ The next day Rangavis wakes up to a Homeric dawn, eager to see the city of Zakynthos, famous for its beauty (an allusion to Theocritus, Idyll 4.32); but when he looks around it is nowhere to be seen, just as Odysseus, having woken up on Ithaca, where he had been transferred overnight by the Phaeacians, fails to recognize his home island. ${ }^{\mathbf{4 7}}$ The mystery is solved when it becomes clear that Rangavis' ship had anchored at the wrong spot away from the city. The stormy seas force them to sail to Argostoli in Cephallenia. Rangavis and his friends set foot on Greek land for the first time and at the hotel they satisfy their hunger like Homeric heroes. ${ }^{48}$

\section{The Great Hunt: Lacedaemonian, English, and Iliadic "Leons" and lions}

In the Odyssey the confrontation with the suitors leads to an archery contest. Odysseus wins the contest and kills the suitors. In Scott's Ivanhoe we have an 
Iliadic development: the siege of the castle of Reginald Front-de-Boeuf for the liberation of two abducted Helens, Rowena and Rebecca. ${ }^{49}$ The Lord of Morea is concluded with the "Great Hunt" $(\eta \mu \varepsilon \gamma a \dot{\lambda} \eta \eta \theta \dot{\eta} \rho a)^{\mathbf{5 0}}$ in the mountains around Andravida, an episode invented by Rangavis. Based on its conclusion alone, the hunt appears to be a covert military operation for the capture of the Greek insurgents. What Geoffrey announces to his guests at the end of chapter 23 is a regular hunting expedition. ${ }^{51}$ There is no mention of the insurgents, though he had been "tracking" them down for some time $\mathbf{5 2}^{\mathbf{2}}$ and, most importantly, he had been doing so at the same time as he was moving from place to place in order to gain time and thus win from Robert the Lordship of Morea. Above all the hunt is a combined political operation and Geoffey's crowning achievement: he uses it as a pretext to thwart the departure of Agnes,${ }^{53}$ niece of the Latin emperor of Constantinople, and thus engineer the marriage with his son; and as an opportunity to win the support of the Greek insurgents -where he succeeds-and especially that of Leon Chamaretos - where he fails. From a narrative viewpoint it is a brilliant move in terms of the dramatic condensation of events.

All parties interested are present in the hunt and all look forward to it, each for his / her own reasons: Petraleifas is expecting to see Anna betrothed to the younger Geoffrey, Anna is hoping to seek the protection of Gautier, Robert sees an opportunity to display generosity of spirit, etc. ${ }^{54}$ Only Leon Chamaretos is absent, whom the perfidious Petraleifas has imprisoned in his house. ${ }^{55}$ Those who win the day are Gautier -who turns out to be the nephew of the Duke of Athens- and of course Geoffrey de Villehardouin. At nightfall Geoffrey leads the hunting party to a forest glade where a banquet takes place to celebrate the "double bonds" of Anna and Gautier, Agnes and the younger Geoffrey. ${ }^{\mathbf{5 6}}$ As noted above, in The Chronicle of Morea both marriages take place after the death of Geoffrey I.

Having learned from Raimondos that the insurgents have gathered inside the Wolfs Cave and are surrounded by his soldiers, Geoffrey leads his guests to that place. In the meantime, Leon Chamaretos has escaped from his prison and is following the party unnoticed. Inside the Wolf's Cave Voutsaras, next in line among the Greek leaders, announces that "it's time for the lions to come out of the caves and chase the ravening wolves" and wonders where the head (chairman) of the gathering (= Leon Chamaretos) is. Then Geoffrey appears with his party, announces that they are surrounded and reads aloud the names of the insurgents finding all of them present. Chamaretos emerges from behind and protests that his name is not included; Geoffrey shows him the list and then Chamaretos 
realizes that Petraleifas has betrayed him and that the upper part of the list containing his name has been torn off. ${ }^{\mathbf{5 7}}$ Geoffrey accuses the insurgents of treason but at the same time offers his forgiveness, explaining that "it is the love of the subjects that constitutes the strength of government, and government is fed on mercy". Most of the surrounded Greeks acclaim Geoffrey as Lord of Morea and put their swords down. The reconciliation of conqueror and conquered is fully in the spirit of Scott's Ivanhoe and confirms that Geofrey, in terms of his ultimate vision, stands for King Richard and not for Prince John. But Leon Chamaretos rejects Geoffrey's magnanimous offer of reconciliation and kills himself. Then Voutsaras addresses the following solemn comment to Geoffrey: "Your highness ... the last of the Lacedaemonians is dead; ${ }^{\mathbf{5 8}}$ it is only now that you have truly become The Lord of Morea". With these words the novel ends. $^{59}$

Leon Chamaretos is a shadowy figure, and historians have proposed different reconstructions of the real person. ${ }^{60}$ In my view Rangavis' choice of him was motivated by purely literary and ideological reasons. They all come together in his name, which combines echoes of ancient history, Walter Scott and Homer. Chamaretos does not appear in The Chronicle of Morea but the Byzantine historian Nicetas Choniates mentions him as "ruler of koile Lacedaemon and tyrant of the Lacones". In Rangavis Leon is a Lacedaemonian who tried to defend Sparta against the Franks putting up a vain five-day resistance; ${ }^{\mathbf{6 1}}$ his hero is Spartan Leonidas and his three hundred that fell at Thermopylae; ${ }^{\mathbf{6 2}}$ and his ideology is "victory or death", ${ }^{\mathbf{6 3}}$ famous from the farewell words of Spartan mothers to their sons departing for battle. ${ }^{64}$ The name Leon would thus evoke the desperate heroism of Leon-idas and his three hundred Spartans, while the name Chamaretos could suggest in Greek a meaning like "fall of bravery" (or "fallen bravery"). ${ }^{65}$

During the tournament of Book 4 -an event which, like the hunt, has a function complementary, preparatory, or equivalent to war- Leon appears disguised as the Black Knight, whom Rangavis, in the authorial intervention quoted above, declares he has drawn from Scott's famous Black Knight. The armors in both novels conceal figurative "lions", respectively Leon Chamaretos and Richard Coeur-de-Lion, Richard the Lionheart, but Chamaretos' choice of color conveys his grief for "the dark clouds of death that have spread over Greece", as he says at one point. ${ }^{\mathbf{6 6}}$

In literary terms the Great Hunt that concludes the novel and its preparation involve a constant interplay between insurgents and wild animals. For instance, 
Voutsaras has chosen to live on the mountains enjoying the freedom of wild animals, and Chamaretos talking to Anna laments the fact that he is forced to live a wolf's life; ${ }^{67}$ the fires lit on the mountain top are signs calling the insurgents to gather but could also serve to bring the animals down from the mountain; ${ }^{68}$ and it is certainly no coincidence that two structurally pivotal acts of the drama (chapters 14 and 28) are played out in the Wolf's Cave, the gathering place of the insurgents. One issue raised during the first gathering of the insurgents in the Wolf's Cave in chapter 14 is the identity of the "lion": some among them fear that their action may "arouse the pacified lion" (the Franks), but Leon Chamaretos replies that they take themselves for rabbits or deer while in fact they are "lions", and lions would rather fight and die as free men, like their Lacedaemonian ancestors, than live in slavery. ${ }^{\mathbf{6 9}}$ When in the last chapter Voutsaras announces that "it's time for the 'lions' to come out of the caves and chase the ravening wolves" and wonders where the head (chairman) of the gathering is, Geoffrey appears and assumes the duties, but next Leon Chamaretos shows up. It would appear that there are two "lions" in the story but with entirely different ideologies.

The lion-like ideology of Leon Chamaretos is given an emblematic literary expression during the tournament. Leon, strong but heavy and clumsy like Richard the Lionheart, fights Gautier, his rival for the hand of Anna, who moves with agility and grace. The raging Leon throws himself violently against Gautier seeking victory or death, like the lion in a famous Homeric simile - the only simile in the Iliad that portrays a lion at bay but with a heart as "brave" as that of the "lion-hearted" king of England:

"Like a lion which when it senses that it is fighting a superior opponent throws itself with rage to meet death rather than suffer the shame of defeat, thus the Black Knight retreated two steps, and next he rushed furiously against his opponent's spear, which was shattered on his breast with a loud crash".

(The Lord of Morea, p. 62)

"And on the other side the son of Peleus rushed against him like a lion, a ravening lion that men are eager to slay, a whole people that has gathered together; and he at the first caring nothing of them goes his way, but when one of the youths swift in battle has struck him with a spear-cast, then he gathers himself with his mouth wide open, and foam appears about his teeth, and his mighty spirit groans in his heart, and with his tail he lashes his ribs and his flanks on both sides, and rouses himself to fight, and with glaring eyes he rushes straight on in his fury, whether he slay some man or himself be slain in the foremost throng; so was Achilles driven by his fury and his gallant heart to go out to face greathearted Aeneas".

(Homer, Iliad 20.164-175, trans. by A. T. Murray / William Wyatt) 
The impulse that in Homer drives the lion to rush fiercely against the hunters' weapons, seeking death rather than the shame of defeat, is the same impulse as that behind Leon's "Lacedaemonian" ideology. In the tournament Gautier's spear is shattered against his breast, so he seizes his opponent with his strong arms and throws him to the ground unconscious. Leon's concluding fight is not, however, against physical violence but against the "chains of generosity and gratitude" which Geoffrey sought to impose on the Greek nation and which, as Leon bitterly notes, "are harder to break than iron and adamant". Leon had, in the words of the narrator, already "broken his sword against the iron armor of the Franks", ${ }^{70}$ but the dagger he now drives against his own breast will not break.

When victory is impossible, death is the only alternative and the only path to freedom. Just before he dies, Chamaretos opens his eyes and sees Anna's tearful eyes above. He confesses to have often seen in his dreams Freedom coming down to him in her shape and breathes out his last words, and life, with epic lines inspired by the most famous suicide in ancient epic tradition, the liberation of the struggling soul of Dido as she dies in Virgil's Aeneid: "Your tears are Iris to me, thanks to whom my soul is liberated and flies winged to heaven". ${ }^{11}$

\section{The Heroine of the Greek Revolution}

Stephanos Xenos' The Heroine of the Greek Revolution was published in 1861 in London, where the author had been living since 1847 engaging in business. ${ }^{\mathbf{7 2}}$ In $19^{\text {th }}$ century Greece it enjoyed great popularity; for its readers it also played the role of a History of the Greek War of Independence because of its rich historical documentation, especially from foreign sources. ${ }^{\mathbf{7 3}}$ The novel is about Andronike and Thrasyboulos, a couple that pledge mutual love before the War of Independence breaks out; the beginning of the war finds them in different locations, they engage separately in the armed struggle, fight in all the major battles and get acquainted with all the major heroes; they meet again during the siege of Missolonghi, where Thrasyboulos is wounded and dies. Andronike will die later in a Russian convent after Greece has won its independence.

Despite opinions to the contrary, neither the subject, which is the account of a long war with numerous episodes rather than an event within it, nor the heroically exaggerated actions of the protagonists, nor the romantic conclusion qualify for association with Scott's novels. ${ }^{\mathbf{7 4}}$ This two-volume, one-thousandpage long novel teems with historical, mythological and archaeological references to Greek and Roman antiquity. The reader is given the impression that he/ she is 
reading one of the many travelers' accounts where modern and ancient Greece merge. ${ }^{75}$ Chapter 21 of volume 1 , however, gives an idea of the writer's view of Byzantine Hellenism. ${ }^{\mathbf{7 6}}$

The first meeting of the couple is indicative of the novel's obsessive engagement with ancient Hellenism and the programmatic role assigned to ancient epic. When Thrasyboulos first sees Andronike, she is tending her sheep in the mountains of Arcadia, where the people still worship Artemis and Pan; she looks like a reincarnation of an ancient deity or mountain nymph in terms of

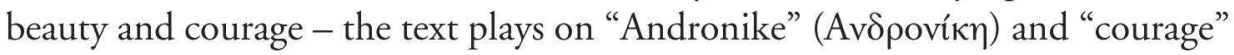
(avopsía); her sheep and dogs bear ancient names. Especially relevant to our discussion is the following conversation:

"-Shepherd girl, wait ... do you know how to read?" -"Forgive my laughing ... can you understand this book?" She retorted. And she took a little book out of her garment and showed it to him.- "These are the rhapsodies of the Iliad!! How is it possible that you, a shepherdess, understand this book?" He cried out retreating in amazement".

(The Heroine of the Greek Revolution, vol. 1, pp. 73-74)

Scott's typical hero, as introduced in Waverley, has a good classical education that may play a role in his relationships and in the development of the plot. But Andronike's erudition (she knows Homer and Pindar by heart, history and mythology) looks and is -to use Harry Shaw's term- "fictionally improbable" by comparison with that of Scott's heroines, who acquire it in an entirely different environment; and so are her military feats by comparison, for instance, with Scott's Helen Campbell in Rob Roy (any comparison with the Queen Elizabeth of Kenilworth, as has been suggested, is simply ridiculous). Despite the poor literary quality of the passage, the brandishing of the volume of the Iliad is multiply significant: it underscores the role of Homer, who, in the words of Adamantios Korais, was the common educator of the Greek nation, and his heritage to modern Greece; ${ }^{77}$ it highlights the generic links between epic and novel of which I spoke earlier; and, finally, it alludes to martial valor and the heroes of Homer's Iliad-which was the leading ancient war epic- as models for the fighters in the Greek War of Independence to whom they are frequently compared in the narrative. 


\section{Loukis Laras}

Dimitrios Vikelas spent twenty years in London (1852-1872) engaging in commercial activity. ${ }^{78}$ Loukis Laras, the novel he published in 1879 , initiated the dialogue between Greeks living in Greece and Greeks living abroad. The hero of the novel, the son of a merchant, flees from Smyrna at the outbreak of the War of Independence, and sails to the island of Chios, where he witnesses the massacre of 1822, and from there to the island of Tinos, where he starts a trading business. Unlike the heroes of Stephanos Xenos, he does not take an active part in the events and does not fight. He flees from place to place in order to survive and his aspiration is a trading business in peaceful times; he eventually reaches London, where he settles down and fulfills his dream. This is originally a true story told in the 1870 's by a Chian Merchant settled in London (in the novel itself the voices of old and young Loukis interact throughout). ${ }^{79}$

It has been suggested that Vikelas "is the first and only Greek writer to write a historical novel modeled after Scott's novels, adhering with veneration to the principles set by the Scottish novelist". ${ }^{\mathbf{8 0}}$ This argument is based on the author's engagement in systematic research in order to prepare an accurate historical background for the novel, on the inclusion in the narrative of three historical personalities (though in minor roles), on the fact that the story is about a major historical event (the massacre of Chios) that affects the life of individuals, and finally, the fact that the protagonist is an ordinary hero like those of Scott. One could, however, object that neither the type of crisis nor the hero reflect the principles on which Scott builds his novels. Obviously the Greek War of Independence is different from the struggles that form the background to Scott's novels, ${ }^{81}$ and hence, I would say, no action "to bring the extremes into contact with one another" can come into consideration. Such action is, in addition, made impossible by the conduct and character of the protagonist: unlike the average hero of Scott's novels, Loukis Laras does nothing but flee from the enemy right from the beginning and never takes any initiative of the sort described above leaving aside the fact that his obsession with trade is hardly a priority with the idealistic and romantic Waverley type of hero.

Gone the same way as the heroic approach to the War of Independence we encountered in Xenos' The Heroine, is the glorious past of Greece. There are three references altogether to classical antiquity in this novel - all to Homer but all providing an unheroic perspective on the Homeric epics. ${ }^{82}$ Talking of the massacre on Chios the narrator says that "each family suffered an 'Iliad' of 
calamities"; with regard to the difficulties of navigation in the Aegean he notes that "whoever is unable to wait fifteen days for the steamship to arrive ... is forced to expose himself to wanderings similar to those of Odysseus and his comrades"; and finally on another occasion he points out that the fiancé of his elder sister "found refuge on the island of Tinos after an 'Odyssey' of misfortunes". ${ }^{83}$

\section{N O T E S}

1 Alexandros Papadiamantis' The Gypsy Girl published in 1884 is the first novel in which Byzantium provides the setting (its action unfolds on the eve of the Fall of Constantinople) and eastern Orthodox culture is one of its three ideological poles (the other two are ancient Hellenism and western Catholic culture).

2 This may be the period of the War of Independence, of Ottoman occupation, Frankish domination of the Peloponnese (The Lord of Morea discussed below), or the Venetian domination of Crete (The Cretan Weddings by Spyridon Zambelios, 1871). The dramatic time of Achilles Leventis' Tasso (1858) are the years of Turkish occupation, but the author, through embedded narrative, manages to bring in Venetian occupation of western Greece as well. Finally, the action of Emmanuel Roidis' Pope Joan (1866) is located in medieval Europe though Joan pays a visit to Byzantine Athens as well.

3 This is the case with Roidis' depiction of Byzantine Athens.

4 For the history of these publications, see Г. Макри́ৎ (G. Makris), "Xроvıкóv

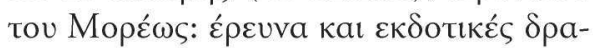

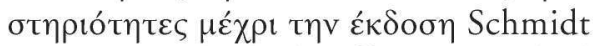
(1904)", in: Elizabeth Jeffreys \& Michael Jeffreys (eds.), Neograeca Medii Aevi V, Oxford 2005, pp. 85-100.
5 Cf. the epigraph for chapter 13 in Ian Duncan (ed.), Sir Walter Scott: Ivanhoe, Oxford 1996, p. 152 (=Ivanhoe, all references are made to this edition). Indirectly, therefore, the topic "Homer and Walter Scott" concerns not only Greek historical novels but also Scott's own novels, which sometimes reveal interesting intertextual relationships with Greek and Roman epic (Homer and Virgil) at the level of plot or character (Scott did not know ancient Greek and quotes Greek texts in translation). Unfortunately secondary literature on Scott's novels and ancient epic is virtually nonexistent. This is true even of Ivanhoe, where the relation to Homer's Odyssey (and to a lesser extent to the Iliad) is announced with epigraphs by Scott himself.

6 On the controversy over the classification of Greek novels of this period as "historical", as well as over their relationship with the novels of Walter Scott, see Lopía Nievíon (Sofia Denissi), To $\varepsilon \lambda \lambda \eta$ -

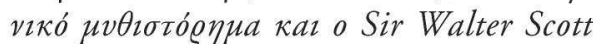
(1830-1880), Athens 1994. As will be seen below, I do not share the conclusions of the book on the individual novels.

7 Georg Lukács, The Historical Novel, translated from the German by Hannah and Stanley Mitchell, Lincoln / London 1983, pp. 30 ff. See, however, Harry E. 
Shaw, The Forms of Historical Fiction: Sir Walter Scott and His Successors, Ithaca I London 1983, pp. $150 \mathrm{ff}$. for the distinction between "disjunctive" and "conjunctive" novels. Basic reading on Scott's novels are also Avrom Fleishman, The English Historical Novel from Walter Scott to Virginia Woolf, Baltimore 1971; and James Kerr, Fiction against History: Scott as Story-teller, Cambridge 1989, who sheds light on the contradiction inherent in Scott's generic mixture of fiction and history, romance and realism.

8 See for instance Lukács, op. cit., p. 49; Shaw, op. cit., pp. 208-209.

9 About 35-40 years in the case of The Heroine and about 60 in the case of Loukis Laras.

10 Similes, a typical feature of ancient epic, are the commonest means and form a most distinctive feature of the style of

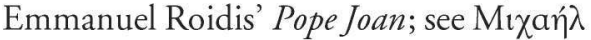

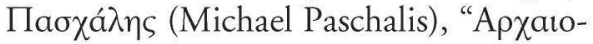

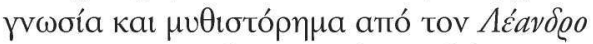

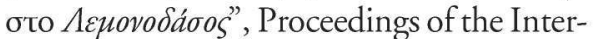
national Conference The Reception of Antiquity in the Byzantine and Modern Greek Novel (Rethymnon 9-10 November 2001), Athens 2005, pp. 169-177. In Scott similes, especially long ones, are rare. The most obvious technique for introducing classical material are quotations: in his novels there is usually a character (a jurist, a teacher, an astrologist, an alchemist, an antiquary - even a mercenary army captain and an executioner) who utters Latin words and phrases copiously and sometimes in comic vein.

11 See Margaret Anne Doody, The True Story of the Novel, New Brunswick 1996, pp. 192-202.

12 He was born in Constantinople in 1809 and was educated first in Odessa and then in Munich, in the military academy. He came to Greece in 1829, serving first as an army officer and then in the civil service. In 1844 he became Professor of Archaeology at the University of Athens and in 1856 Minister for Foreign Affairs. He died in 1892. Despite the burden of his duties, he was a prolific writer of all sorts of poetry and prose in the most varied areas. His best-known work is The Lord of Morea.

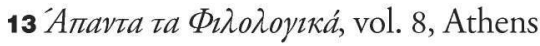
1876, pp. 1-263.

14 On Roidis and classical antiquity, see Paschalis, art. cit.

15 Ivanhoe, cit., pp. 102-103.

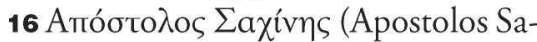

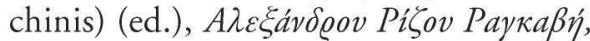

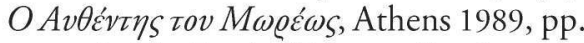
56-57 (= The Lord of Morea, all references are made to this edition).

17 Elsewhere we are told that "the barbarians are unable to understand the language of Greece's immortal ruins" or that "the famous cities of the past are now ruins inhabited by wolves and foxes" (The Lord of Morea, cit., pp. 125, 134).

18 The Lord of Morea, cit., pp. 71-72, 216-217.

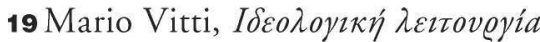

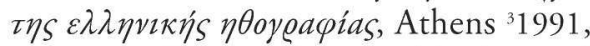
pp. 22-25. For reactions to this view and other approaches see Sachinis' Introduction to The Lord of Morea, cit., pp. 1720; Henri Tonnet, "L'image romantique du passé de la nation grecque dans l'ouvre d'Alexandre Rangavis Le Prince de Morée', L'imaginaire de la nation (1792-1992), Actes de colloque Européen de Bordeaux (1989), Bordeaux 1991, pp. 323-330; Denissi, op.

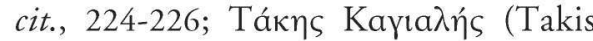

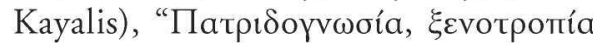

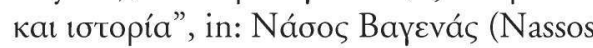




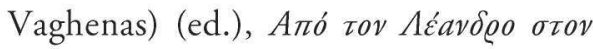

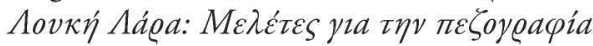

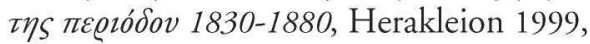

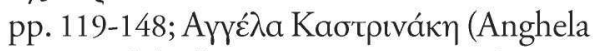

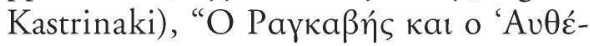

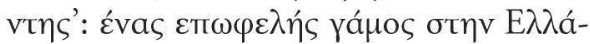
Sa tou $1850 "$, Ta Istorika 17 (2000), pp. 271-288.

$20 \mathrm{I}$ borrow this phrase from Paschalis M. Kitromilides, "On the Intellectual Content of Greek Nationalism: Paparrigopoulos, Byzantium and the Great Idea”, in: David Ricks \& Paul Magdalino (eds), Byzantium and the Modern Greek Identity, Aldershot / Brookfield 1998, pp. 25-33, 27. Passages inserted in later editions of the novel do not affect the overall picture I am presenting. See $\Theta \varepsilon$ o-

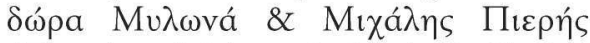
(Theodora Mylona \& Michalis Pieris),

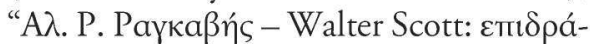

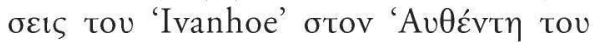

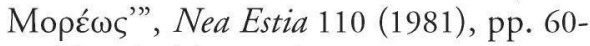
76; Kastrinaki, art. cit..

21 William de Champlitte was Lord (Prince) of Morea from 1204 to 1209 (cf. The Lord of Morea, cit., p. 59, note 3); Geoffrey (Geoffroy) I de Villehardouin ruled from 1210 to 1218 and his son Geoffrey (Geoffroy) II de Villehardouin from 1218 to 1246.

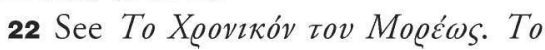

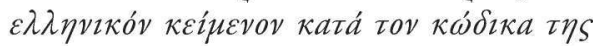

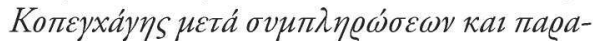

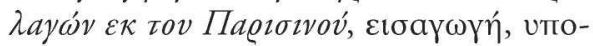

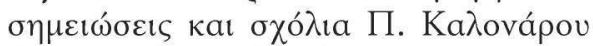
(Petros Kalonaros), Athens 1940, vv. 1847 ff., 2098-2434 (= The Chronicle of Morea, all references are made to this edition).

23 See Mylona \& Pieris, art. cit., pp. 1-6.

24 Mylona \& Pieris, art. cit., pp. 9-11.

25 Denissi, op. cit., pp. 216 ff.; her analysis follows Mylona \& Pieris, art. cit.
26 The Lord of Morea, cit., pp. 34-37, 51, 177, 195, 198-199.

27 The Chronicle of Morea, cit., vv. $2472 \mathrm{ff}$; there Agnes appears as daughter of Robert, the Latin emperor (the story is also briefly told in vv. 1185-1198). It is Rangavis himself who refers the reader to The Chronicle with a note on p. 229. On the actual events and dates see the note on p. 105 of Kalonaros' edition.

28 Geoffrey's qualities and Leon's inadequacies have been pointed out by several scholars, despite differences in interpretation (see for instance Kastrinaki, art. cit., the most recent study of the novel's ideology).

29 Cf. Mylona \& Pieris, art. cit., p. 13.

30 The Lord of Morea, cit., pp. 29, 50, 71-76, 169-173, 222-226 and passim. Careful reading of pp. 71-76 shows beyond any doubt that Leon has no specific plan in his mind, only the vague dream of "resurrecting the holy throne of Byzantium”.

31 The Lord of Morea, cit., pp. 184-193.

32 The Chronicle of Morea, cit., vv. $7970 \mathrm{ff}$. It is Rangavis himself that refers the reader to this passage of The Chronicle with a note on p. 233. There is much confusion, however, in The Chronicle, on which see the note on p. 322 of Kalonaros' edition.

33 John Henry Raleigh, "Ulysses and Scott's Ivanhoe", Studies in Romanticism 22 (1983), pp. 569-586, 572.

34 See Michael Paschalis, «Ta Bovko-

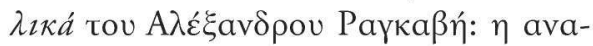

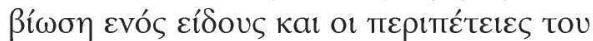

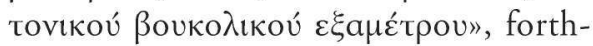
coming in Kondyloforos.

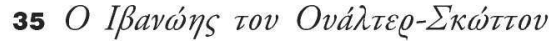

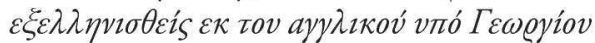

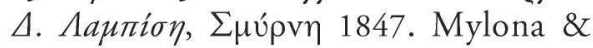


Pieris, art. cit., p. 8, note 32, believe that Rangavis consulted this translation and not the English original.

36 At one point the pretexts of Raimondos, Geoffrey's agent, through which he delays the organization of an armed escort for Robert's return, are compared to Penelope's weaving and unweaving, by means of which she sought to delay marriage to one of the suitors ("In my country" he said "they tell the following story: there was a woman, very skilled in the craft of weaving, who had the weird obsession of undoing during the night what she wove during the day; in this way she kept herself busy all the time while her cloth did not get any larger. I suspect that our recruiting advances like the cloth of our Penelope", The Lord of Morea, cit., p. 81). But when Nonnos (Petraleifas' agent who had orders to speed up Robert's arrival) informs Robert of the stratagem, Raimondos abandons the pretexts just as Penelope is forced to complete the weaving when a woman informs the suitors of her guile. An allusion to the Odyssey is also found during Robert's stay in Venice: the sumptuous hospitality with which the Doge of Venice manages to delay his departure are compared to the pleasures of Circe ("...they were forced to surrender themselves to the pleasures of Circe-like Venice...", The Lord of Morea, cit., p. 97).

37 See especially vv. $2098 \mathrm{ff}$.

38 When Geoffrey is proclaimed Lord of Morea, the Greek noblemen are the first to cheer: the detail is added by Rangavis but reflects the spirit of the Chronicle and is in harmony with the conclusion of the novel where most of the insurgents acclaim him as Lord of Morea (cit., p. 247). In an authorial intervention
Rangavis explains that "Villehardouin was generally loved by the Greeks, that is by those who were unwilling to resist and accepted foreign rule", because his rule was moderate and he respected the Orthodox religion, feudal privileges and the rights of the people (The Lord of Morea, cit., p. 182; on his achievements see pp. 30, 44, and passim). For a different reading of these passages see Kastrinaki, art. cit., pp. 274-275.

39 The Lord of Morea, cit., pp. 32-33. Raimondos comes from France, where he had been sent to prevent the arrival of the rightful successor, disguised as a monk (like Ivanhoe); only one person knows who this character actually is (as it happens in Homer and Ivanhoe); and he retires to talk with Geoffrey (as Ivanhoe does in Scott with Rowena).

40 Cf. Tonnet, art. cit., p. 330, who sees in Petraleifas' moves a combination of Odysseus' cunning with the subtlety of Byzantine diplomacy (same in Henri

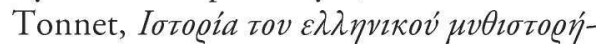
Matos, Athens 1999, p. 122).

41 The ship is called "Leon" (= "lion"), obviously named after the symbol of Venice (The Lord of Morea, cit., pp. 104 ff.). Robert was deliberately delayed by the Doge in Venice (on instructions received from Geoffrey) longer than anywhere else, and it is this delay above all that cost him the Lordship of Morea. It is possible that the ship "Leon" stands for Venice that hindered Robert's timely arrival at the Peloponnese and this may not be unrelated to the fact that Geoffrey, the other claimant to the Lordship, has an opponent on land called Leon Chamaretos; cf. section 3 below on "Leons" and lions.

42 The Lord of Morea, cit., pp. 107-116.

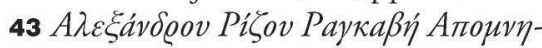




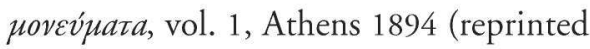
1999), pp. 200-223. The account of his coming to Greece was published sixty-five years after the events occurred. No original notes taken during the journey survive (assuming there were any), just the manuscript of the Memoirs.

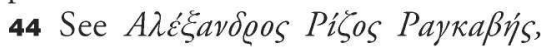

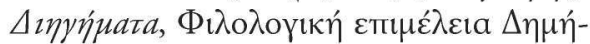

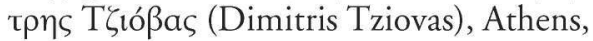
1999, vol. 2, pp. 132-164.

45 "Eventually one evening we sighted from a distance towards the east some blackish, solid clouds and with unspoken bliss we heard that these were at last the much desired Ionian islands -then belonging to England but being Greek from every other aspect- the islands of the Phaeacians and of Odysseus". Cf. Homer, Odyssey 5.279-5.281, trans. by R. D. Dawe: "... and on the eighteenth day the shadowy mountains of the Phaeacians' land appeared, at the point nearest to him. It looked like a shield in the misty sea".

46 "And we saw the islands and slept a comforted sleep, and Greek dreams from the ivory gate came to us throughout the night; but in the morning we found out that getting near them was not without difficulties...". Cf. Homer, Odyssey 19.56019.567, trans. by R. D. Dawe: "Stranger, dreams, you know, are intractable and their message jumbled; not everything comes to happen for men. There are two sets of gates of strengthless dreams: one lot are made with horns, the others with ivory. Those which come through the sawn ivory ones, they are harmful, bringing tales which are not to be fulfilled. But those which come outside through the polished horns, they bring true fulfillment when one of mortal men sees them".

$\mathbf{4 7}$ "Dawn had just smiled on us when
I rushed to the deck eager to see Greek Zakynthos, famous for its beauty. I turned my bewitched eyes around ... but could not understand what was that caused the city of Zakynthos to be hidden from view". Cf. Homer, Odyssey 2.1: "When she that is born early appeared, rosefingered Dawn"; also Homer, Odyssey 13.194-13.196, trans. by R. D. Dawe: "That is why everything kept appearing to look different to their master - the continuous paths, the harbors where all may anchor, the sheer rocks and the flourishing trees".

48 "When we had satisfied our desire for drink and food...". Cf. Homer, Odyssey 14. 454: "when they had satisfied their desire for drink and food".

49 Raleigh, art. cit., p. 572.

50 The Lord of Morea, cit., pp. 215, 227.

51 The Lord of Morea, cit., p. 213.

52 The Lord of Morea, cit., pp. 165, 191.

53 The Lord of Morea, cit., p. 227.

54 The Lord of Morea, cit., pp. 213, 226-227.

55 The Lord of Morea, cit., pp. 220-222.

56 The Lord of Morea, cit., pp. 234, 243.

57 It was Geoffrey who, in an effort to protect Chamaretos when he was given the list by Petraleifas, tore off the corner of the paper that bore his name.

58 Tonnet, art. cit., p. 328 correctly sees here an allusion to Philopoemen who was called "the last of the Greeks" (Plutarch, Philopoemen 1.7).

59 The Lord of Morea, cit., pp. 244-248.

60 For interpretations of the scanty

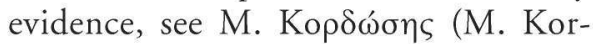

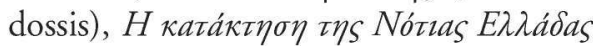

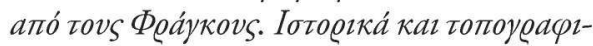

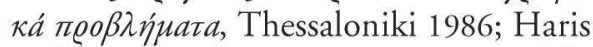
Kalligas, Byzantine Monemvasia: The Sources, Monemvasia 1990; A $\lambda \varepsilon^{\prime} \xi \eta \varsigma$ Г. K. $\Sigma a \beta \beta i \delta \eta\rceil$ (Alexis Savvidis), “Тa тро $\beta \lambda \eta ́$ - 


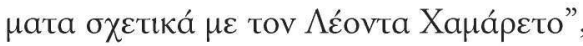
Byzantinai Meletai 3 (1991), pp. 350-383.

61 "This young man was Leon Chamaretos ... Having rekindled the last spark of ancient valor amid the ashes of Sparta, Leon hoped to resist the torrent of the Franks and withstood their siege with great bravery for five days; but in the end Sparta suffered its final fall and Chamaretos' sword was shattered against the iron armor of the knights" (The Lord of Morea, cit., pp. 40-41, authorial comment). On Chamaretos' vain defense of Sparta see also The Lord of Morea, cit., pp. 31, 70, 7475 ("I surrendered him the keys of Lacedaemon"), 76, 125. The five-day war that led to the surrender of the Lacedaemonians is an element derived from The Chronicle of Morea, cit., v. 2055, where, however, there is no mention of Chamaretos.

62 "There was a time when the three hundred dead bodies of her [Sparta's] sons were able to check the torrent of the whole of Asia" (The Lord of Morea, cit., p. 70, spoken by Chamaretos to Anna); "There were days when the three hundred bodies of her [Sparta's] sons checked the torrent of entire Asia ... Our ancestors either won or died" (The Lord of Morea, cit., p. 133, Chamaretos' speech to the insurgents).

63 "Our ancestors either were victorious or died" (The Lord of Morea, cit., p. 71, Chamaretos speaking to Anna).

64 "...when mothers armed their sons, they wished and bade them rather to be brought back dead on their shields than to come back alive without them" (The Lord of Morea, cit., p. 133, Chamaretos' speech to the insurgents).

65 When a proper name is inserted in a narrative it may release the semantic potential its components possess or gene- rate pseudo-etymological meaning; this is commonly done through semantic association with other words (= semantic clusters; see the introduction to Michael Paschalis, Virgil's Aeneid: Semantic Relations and Proper Names, Oxford 1997). Greek xauai ("on the ground"; "to earth") occurs as first component of several ancient and modern Greek words; in ancient Greek it is common with verbs

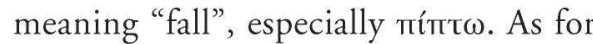
арєтฑं, in ancient Greek it indicated, among other things, "valor" or "bravery". Rangavis' archaizising style is very sensitive to ancient Greek usage. When the author first introduces Chamaretos (pp. 40-41), he gives a short narrative that renders the semantic content of his name: he rekindled the last spark of "ancient valor"

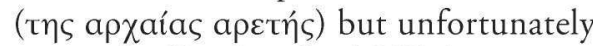

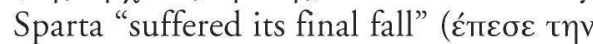

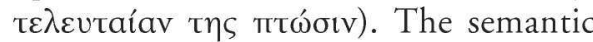
potential of "valor" and "falling" is unfolded in several passages and episodes.

66 "How can my thoughts not be dark, when a black veil of death has spread over my country?". Chamaretos is replying to Anna's comment that his mind is always "fed with dark ideas" (The Lord of Morea, cit., pp. 124-125).

67 The Lord of Morea, cit., pp. 130, 157. As pointed out by Kastrinaki, art. cit., p. 272, the words of Voutsaras pick up the opening lines of the famous patriotic Thourios (Battle Hymn) composed by Rigas Velenstinlis.

68 The Lord of Morea, cit., pp. 192, 136, 215, 220.

69 The Lord of Morea, cit., p. 133.

70 The Lord of Morea, cit., p. 41.

71 Cf. Virgil, Aeneid 4.693-4.705.

72 Xenos was born in Smyrna in 1821 and died in Athens in 1894. 
73 Denissi, op. cit., pp. $230 \mathrm{ff}$.

74 For discussions of The Heroine as a novel modelled after Scott, see Denissi, op. cit., pp. 230-252.

75 Travelers used to take note only of vestiges of Greek antiquity in the people, the buildings and the landscape of modern Greece. References to travelers occur occasionally in the novel: see $\sum \tau \varepsilon \dot{\varepsilon} \varphi$ avos $\Theta$. छÉvos, $H$

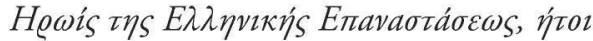

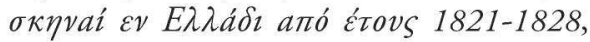
Фı

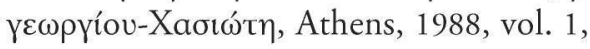
pp. 69, 72, 94, 379.

76 In a kind of Virgilian katabasis the Patriarch of Constantinople Gregorios V, who was brutally murdered by the Turks, appears to Thrasyboulos in a dream and takes him through a cave opening to see the shades of Christian saints and Byzantine emperors and the two gates of Hellenism: the golden gate of past glory and the gate of martyrdom. The account involves criticism of "corrupt" Byzantine emperors.
77 In chapter 48 of vol. 1 a dance of Chios is said to date back to Homer's days and specifically to a famous description on the Shield of Achilles, Iliad 18.587-18.604.

78 Vikelas was born in Ermoupolis in 1835 and died in Athens in 1908.

79 For the author's life, his work, the actual story told by the Chian merchant, and the text and readings of Loukis Laras, see Mapıávva $\Delta$ ítoa (Marianna Ditsa),

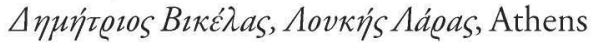
1991 (=Loukis Laras, references are made to this edition).

80 On Vikelas and Scott, see Denissi, op. cit., 1994, pp. 256-293, with earlier literature.

81 As admitted by Denissi, op. cit., p. 282.

82 It should be mentioned at this point that in 1866 Vikelas published a translation of book 6 of Homer's Odyssey.

83 Loukis Laras, cit., pp. 122, 139-140, 175. The passages of pp. 122 and 175 have proverbial overtones.

\section{П E P I ^ H $\Psi$ H}

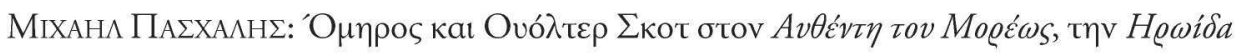

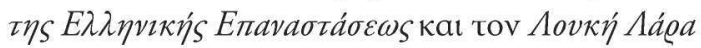

atrovoía tov vó $\mu$ 1.

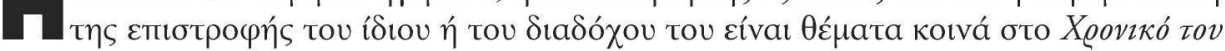

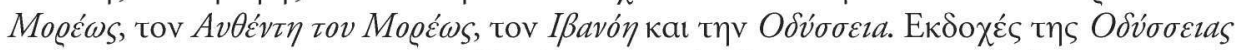

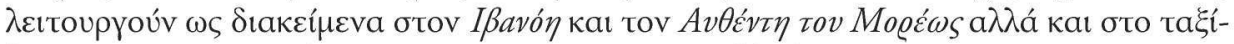

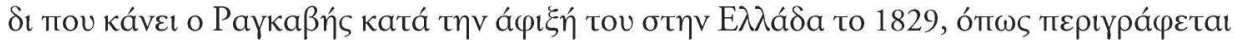

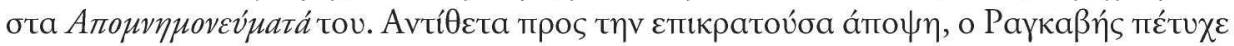

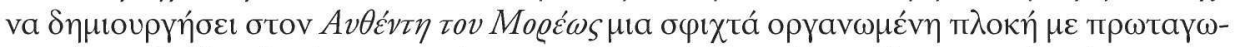

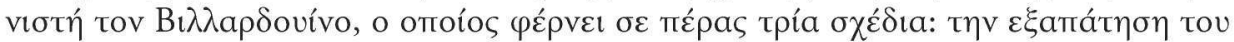

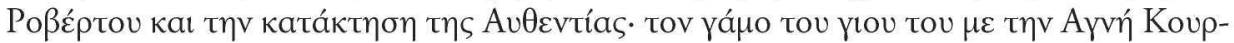

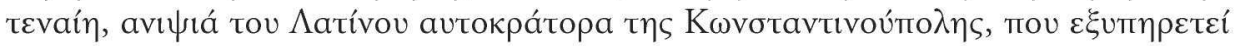




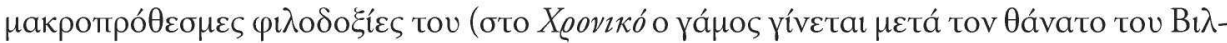

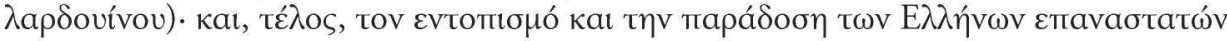

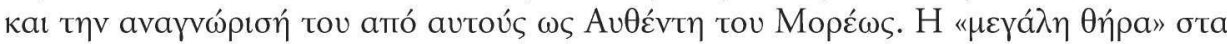

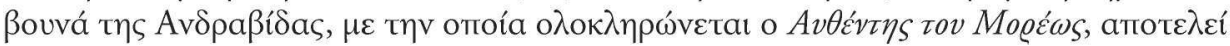

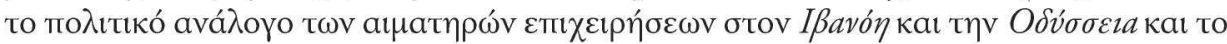

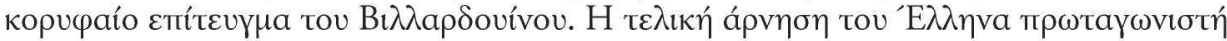

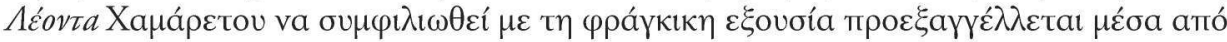

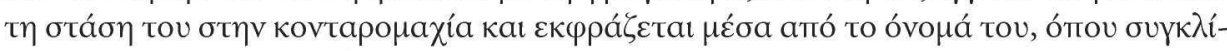

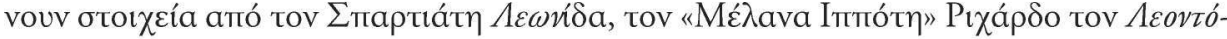

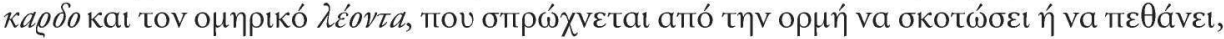

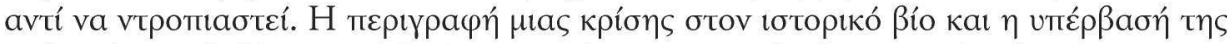

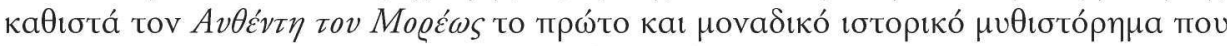

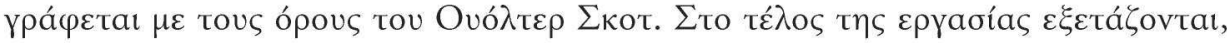

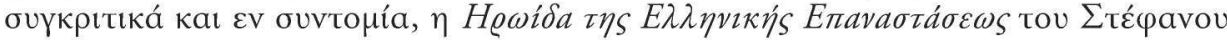

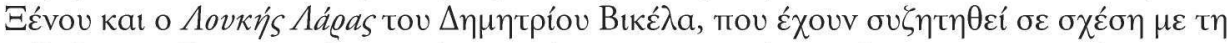

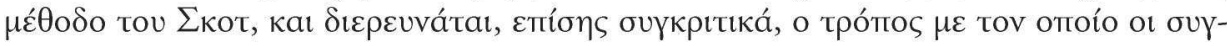

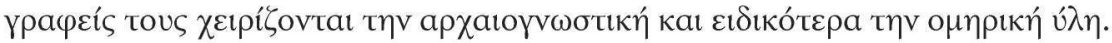

